ROCZNIKI HUMANISTYCZNE

Tom LXIX, zeszyt 4 - 2021

DOI: http://doi.org/10.18290/rh21694-6

ALINA BARCZYK

\title{
PROJEKTY GIOVANNIEGO BATTISTY GISLENIEGO DLA WARSZAWSKIEJ JURYDYKI LESZCZYŃSKICH W ZBIORACH DREZDEŃSKICH
}

W zbiorze szkiców Giovanniego Battisty Gisleniego w Dreźnie znajdują się projekty dla warszawskiej ${ }^{1}$ jurydyki Leszno, datowane na lata $1650-55^{2}$. Rysunki prezentują elewacje frontowe i rzuty ratusza, dwóch wersji szpitala oraz przykładowej zabudowy szeregowej. Ostatni z wymienionych obiektów dotychczas interpretowano jako wzorzec domów jurydyki Grzybów (Putkowska 27) lub projekt austerii ${ }^{3}$. Szkice obu szpitali były wzmiankowane w literaturze, nie kojarzono ich jednak z Nowym Lesznem. Wprawdzie od początku były łączone z Warszawą, ale nie precyzowano miejsca ich przeznaczenia (Lileyko, Życie codzienne 232) bądź zakładano, że jeden z nich odnosił się do infirmerii funkcjonującej od końca XVI wieku przy Zamku Królewskim (Konarski 68; Putkowska 304; Tkaczyk 455).

Dr Alina Barczyk - Uniwersytet Łódzki, Instytut Historii Sztuki, Katedra Historii Architektury; adres do korespondencji: ul. Narutowicza 65, 90-131 Łódź; e-mail: alina.barczyk@uni. lodz.pl; ORCID: https://orcid.org/0000-0002-6596-8915.

${ }^{1} \mathrm{~W}$ artykule niejednokrotnie posługuję się pojęciem „warszawska”, choć de facto jurydyka została założona pod Warszawą, poza terenem Starego Miasta. Prawnie Leszno - tak jak pozostałe jurydyki - stało się częścią stolicy na mocy postanowień Konstytucji 3 Maja, ostatecznie wprowadzonych w życie dopiero w 1794 r. (Wyrobisz 518). Termin „warszawska” został jednak dość powszechnie przyjęty w literaturze z zakresu historii i architektury (wspomnieć wystarczy prace: Konarski 68; Miłobędzki 203-204; Putkowska 23; Gawryszewski 15) i pozostaje czytelny.

${ }^{2}$ Rysunki stanowią część tak zwanego drezdeńskiego szkicownika G.B. Gisleniego (nazywanego też szkicownikiem G. Chiaveriego), znajdującego się w kolekcji: Staatliche Kunstsammlungen Dresden, Kupferstich-Kabinett, nr inw. Ca 67/18v; Ca 67/19v; Ca 67/19r; Ca 67/20r; Ca 67/54v; Ca 67/55r; Ca 67/62r. Poszczególne karty poszytu, wśród nich projekt pałacu miejskiego, a także inwentaryzaje oraz projekty dekoracji katedry wawelskiej, były szczegółowo omawiane w pracach Stanisława Mossakowskiego („Pałac Biskupi” 137, 143; „Uroczystości wawelskie" 85-86),

${ }^{3} \mathrm{~W}$ inwentarzu archiwalnym w Dreźnie rysunek został zinterpretowany jako projekt austerii na Lesznie („Herberge in der Privatstadt Leszno des Bogusław Leszczyński”). 
Leszno (Nowe Leszno) było pierwszą świecką jurydyką w Warszawie (Bartoszewiczowie, „Obraz kartograficzny” 92; Bania 138; Główka i Mazur 223; Konarski 68). Zostało założone na prawie chełmińskim w 1648 r. przez Bogusława Leszczyńskiego (AGAD, Zbiór dokumentów pergaminowych, sygn. 1/1/0/-/1696, s.n), przy współudziale jego stryja - Jana (Wegner 232; Sawicki, „Kształty warszawskich ulic” 213; Bartoszewiczowie, „Obraz kartograficzny” 46). Przywilej lokacyjny, potwierdzający fundację, został wydany w 1654 r. przez króla Jana Kazimierza (Rejman 62) ${ }^{4}$. W dokumencie zapewniono równouprawnienie katolików i dysydentów, co w znacznej mierze wpłynęło na charakter jurydyki - chętnie zamieszkiwanej przez protestanckich rzemieślników i kupców, przenoszących się do Warszawy przede wszystkim z ziem niemieckich (Lileyko, Życie codzienne 27) ${ }^{5}$. Z tego samego roku pochodziła „Delineatio Novae Leschnae cum partibus adiacentibus" (il. 1). Plan autorstwa Sebastiana Englerta, znany dziś jedynie z fotografii, jako że spłonął w 1944 r. (Bartoszewiczowie, „Obraz kartograficzny" 73), ukazywał schematyczne rozplanowanie jurydyki (Bartoszewiczowie, „Kartografia miast” 317). Nowe Leszno powstało na obszarze położonym na zachód od wału Zygmuntowskiego, między Starym Miastem a rolą Świętokrzyską - na dawnej ziemi Stanisława Skórczyńskiego (Małcużyński 23; Rejman 64; Główka i Mazur 223) ${ }^{6}$. Układ urbanistyczny był warunkowany przez wymiary gruntu, liczącego około 175-180 m (300 łokci) szerokości (Główka i Mazur 223) i ponad 1011 m długości (Bartoszewiczowie, „Obraz kartograficzny” 92). Zrezygnowano z centralnego placu z rynkiem, natomiast przez środek terenu poprowadzono główny trakt o szerokości blisko $22 \mathrm{~m}$, wiodący od strony miasta rezydencjonalnego Jego Królewskiej Mości na zachód, w kierunku Błonia (Szwankowski 46) ${ }^{7}$. Po obu stronach ulicy - stanowiącej oś kompozycyjną Leszna - wydzielono działki pod przyszłą zabudowę (il. 2).

Jurydyka miała podkreślać pozycję polityczno-społeczną założyciela, w paru słowach należy więc wspomnieć o jego postaci. Bogusław Leszczyński

\footnotetext{
${ }^{4}$ Przywilej był potwierdzany przez monarchów: Michała Korybuta w 1669 r. (AGAD, Zbiór dokumentów pergaminowych, sygn. 1/1/0/-/1697), Jana III w 1676 r. (AGAD, Zbiór dokumentów pergaminowych, sygn. 1/1/0/-/1698), a także Augusta III Sasa w 1745 r. (AGAD, Zbiór dokumentów pergaminowych, sygn. 1/1/0/-/1700).

${ }^{5}$ Zjawisko osiedlania się protestanckich imigrantów na Lesznie stało się szczególnie powszechne za czasów saskich (Kriegseisen 302).

${ }^{6}$ Wał oraz Arsenał zostały oznaczone na wspomnianej wcześniej mapie Englerta (il. 1).

${ }^{7}$ Błonie było oddalone o blisko $35 \mathrm{~km}$ od granic Warszawy. Od 1654 r. należało do Bogusława Leszczyńskiego (Główka i Mazur 223).
} 
(1614-1659) jest uważny za najważniejszego przedstawiciela rodu w swoim pokoleniu (Ciara 14). Urodził się jako syn wojewody bełskiego Rafała oraz Anny z Radzimińskich (Karwowski 26). Wykształcenie zdobywał między innymi w Lejdzie i Padwie, w czasie podróży europejskiej odwiedził też Anglię, Szkocję oraz Francję (Forycki 20). Od 1642 r. był starostą generalnym wielkopolskim. Kolejne etapy w karierze politycznej magnata wyznaczyło objęcie w 1650 r. funkcji podskarbiego wielkiego koronnego, a w 1658 r. podkanclerza koronnego (Karwowski 26; Dworzaczek 107-108). Rozległe, odziedziczone dobra oraz bogate królewszczyzny zapewniały mu dobrą sytuację finansową (Ciara 145). Około 1642 r. przyjął katolicyzm (Dworzaczek 107), nie zapomniał jednak o swoich protestanckich korzeniach - były one zapewne jednym $\mathrm{z}$ argumentów przemawiających za wprowadzeniem wspomnianego równouprawnienia religijnego wśród mieszkańców Nowego Leszna. Wnukiem Bogusława Leszczyńskiego był Stanisław, król Polski (Forycki 20). Ambicje polityczne wpłynęły na chęć założenia podwarszawskiej jurydyki. Przedmiotem zainteresowania magnata stało się zarazem wzniesienie na jej obszarze własnej, reprezentacyjnej siedziby. Architektem, któremu powierzono to zadanie, był Giovanni Battista Gisleni (1600-1672). Zadaniem Włocha miało być też stworzenie szkiców dla wybranych gmachów Leszna (ratusza, szpitala, modelowej zabudowy). Z pewnością nieprzypadkowo kierowany ambicją Leszczyński zwrócił się do jednego z najważniejszych artystów związanych z dworem królewskim ${ }^{8}$.

\footnotetext{
${ }^{8}$ Postać Giovanniego Battisty Gisleniego oraz jego æuvre są powszechnie znane i były przedmiotem licznym badań. Spośród podstawowych not biograficznych wspomnieć można chociażby: Osiecka-Samsonowicz passim; Resmini passim. Etapy kariery twórcy prezentuje artykuł: Tygielski passim. Natomiast nagrobek architekta, znajdujący się w rzymskim kościele S. Maria del Popolo, omawiali między innymi Kapustka passim; Greco passim.

Dogłębne analizy poszczególnych dzieł Gisleniego prezentowali wybitni znawcy jego twórczości - Nina Miks-Rudkowska („Kapela królewska” passim; „Niektóre projekty” passim; „Pałac Bogusława”, passim; „Theatrum”, passim) oraz Stanisław Mossakowski („Galeria” passim; „Gli anni romani” passim; „Pałac Biskupi” passim; „Rzymskie lata” passim; „Uroczystości wawelskie” passim). Wielokrotnie były też omawiane prace włoskiego architekta dla dworu królewskiego, w tym związane z przekształceniami Zamku Królewskiego w Warszawie (np. Lileyko, „Władysławowski Pokój Marmurowy” passim), inwentaryzacją rezydencji wazowskich (np. Wardzyński, Rezydencje królewskie 259-260) i oprawą artystyczną uroczystości pogrzebowych (np. Kret, passim; Żukowski, Żądza chwaty 424-430, 446-447; Kaczorowski 229). Nazwisko twórcy pojawia się w licznych tekstach dotyczących nowożytnej sztuki Mazowsza (np. Wardzyński, „Sztuka nowożytna” 664, 668) i architektury warszawskiej (np. Bernatowicz, „Nowe spojrzenie" 14; Mitra i buława 327). Z najnowszych omówień warto też przywołać notę katalogową dotyczącą albumu zawierającego 116 rysunków Gisleniego z lat 1649-55, prezentowanego w 2019 r. na wystawie „Świat Polskich Wazów” na Zamku Królewskim w Warszawie (Żukowski, Świat polskich Wazów 295-297).
} 
Około 1650 r. Gisleni zaprojektował rezydencję podskarbiego koronnego (Miłobędzki 25; Osiecka-Samsonowicz 175), położoną od strony ulicy Rymarskiej (nr hip. 744; obecnie: Plac Bankowy 3/5). Rysunki, odnalezione przed laty w Mediolanie (Miks-Rudkowska, „Pałac Bogusława” 187-188), prezentują rzut założenia oraz widok wieży. W literaturze lesznieńska siedziba jest czasem nazywana pałacem - pod względem architektonicznym i funkcjonalnym był to jednak parterowy dwór. Główny korpus, wzniesiony na planie prostokąta, miał układ dwutraktowy (il. 3). Po wschodniej stronie sieni („Andito") znajdowało się największe pomieszczenie, oznaczone na planie jako „Sala” - zapewne przeznaczone na funkcje reprezentacyjne. W zachodniej części urządzono apartament mieszkalny, obejmujący przedpokój („Anticam[era]”), sypialnię („Cam[era]”) z alkową („Alcoe”), gabinet („Gabin[et]”) i pokoik („Cam[era]”), być może pełniący funkcję garderoby. Do elewacji frontowej dostawiono galerię prowadzącą do dwóch oficyn o rzutach wydłużonych prostokątów, mieszczących dalsze pokoje i pomieszczenia użytkowe - wśród nich łazienkę („Bagno”). Dwór poprzedzono czworokątnym dziedzińcem, zamkniętym od południa oficyną frontową. W niej mieściła się główna brama („Intrata”), która wychodziła na ulicę Rymarską. W oficynie ulokowano również między innymi stajnię („Stall”) z wozownią („Rimessa”), dwie kuchnie („Cucina”) i piekarnię („Forno”). Za rezydencją rozciągał się ogród. Projekty założenia dworskiego były publikowane w artykule Niny Miks-Rudkowskiej („Zbiór rysunków” passim.). Badaczka zasugerowała wówczas, że Gisleni mógł być odpowiedzialny za tworzenie szkiców dla głównych budowli Nowego Leszna - na przykład ratusza, szpitala czy też wzorcowych domów. Ta teza została słusznie przyjęta w nowszej literaturze ${ }^{9}$. Ostateczne jej potwierdzenie stanowią omawiane w niniejszym tekście projekty.

Warto przyjrzeć się poszczególnym rysunkom dla Leszna, pochodzącym z drezdeńskiego szkicownika tego architekta. Ratusz został zaprojektowany jako budynek murowany, dwukondygnacyjny, na planie prostokąta z ryzalitem wieżowym na osi (il. 4). Bryła zyskała większą przestrzenność dzięki jednobiegowym schodom, umieszczonym symetrycznie po obu stronach wieży i prowadzącym bezpośrednio na pierwsze piętro. Naroża budowli są boniowane, a profilowany gzyms oddziela parter od piętra. Z wysokiego dachu

${ }^{9} \mathrm{~W}$ Stowniku architektów i budowniczych środowiska warszawskiego XV-XVIII wieku realizacje Gisleniego związane z wytyczeniem obszaru i zaprojektowaniem głównych budowli jurydyki zostały wymienione w grupie dzieł atrybuowanych (Osiecka-Samsonowicz 177). Jako pewne zostało potwierdzone autorstwo rezydencji Leszczyńskiego na Lesznie (175). 
wyprowadzono lukarny. W obrębie piano nobile prosto zamknięte okna mają uszakowe obramienia i zwieńczone są wydatnym, profilowanym gzymsem. Bogatszą artykulacją odznacza się wieża, której naroża ujęto kolejno: pojedynczymi, szerokimi półfilarami (?) w przyziemiu ${ }^{10}$; parami pilastrów na pierwszym piętrze; pojedynczymi pilastrami na trzeciej kondygnacji i wreszcie - w partii najwyższej - prostą ramą permutacyjną. Nad wieżą góruje baniasty hełm. Zróżnicowanie wprowadzono nie tylko w podziałach architektonicznych wieży, lecz i w otworach drzwiowych oraz okiennych. Wejście z parteru i prześwit pierwszego piętra zamknięto łukami półkolistymi. Na drugim piętrze niewielkie okno zyskało wykrój prostokątny. Wreszcie czwarta kondygnacja mieściła tarczę zegarową. Architektonicznie bryła dominanty wysokościowej przywodzi na myśl wieżę z innego, bardzo schematycznego rysunku Gisleniego, prezentującego dwór Opalińskich (il. 5). W tym przypadku liczba kondygnacji została ograniczona do trzech, brakuje też artykulacji naroży. Analogię można jednak dostrzec w rozwiązaniu kompozycyjnym (począwszy od dolnej kondygnacji widoczne są: półkoliście zamknięte wejście; okno o czworokątnym wykroju; zegar; baniasty hełm w zwieńczeniu).

W lesznieńskim ratuszu główna i tylna elewacja miały posiadać po trzy osie, a boczne po dwie. Budynek miał mieć układ trójdzielny, dwutraktowy (il. 6). Rzut wyraźnie pokazuje integrację partii wieżowej z wnętrzem. Na lewo od mieszczącej się w wieży sieni widoczna jest wielka, przesklepiona sala, z pewnością mająca pełnić główne funkcje reprezentacyjno-użytkowe. Mimo skromnej skali obiektu architekt podjął próbę maksymalnego podniesienia walorów rzeźbiarskich bryły (wieża, schody) i wprowadzenia elementów dekoracyjnych odpowiadających statusowi zleceniodawcy - zamożnego właściciela jurydyki. Projekt niestety nie doczekał się realizacji. Ratusz w południowej pierzei traktu - prawdopodobnie z powodu „potopu szwedzkiego” wzniesiono dopiero w latach 80. XVII wieku w konstrukcji drewnianej (Putkowska 306). Murowany obiekt powstał dopiero w czasach stanisławowskich wedle koncepcji Szymona Bogumiła Zuga ${ }^{11}$.

\footnotetext{
${ }^{10} \mathrm{Na}$ rysunku elewacji podpory są masywne i sprawiają wrażenie silnie ryzalitowanych, podczas gdy na rzucie pierwszego piętra lico osi środkowej tworzy linię prostą. Te elementy mogły więc być szerokimi, płaskimi pilastrami.

${ }^{11}$ Ratusz znajdował się na posesji noszącej nr hip. 722 (Sawicki, „Jurydyki” 4). Prace prowadzono około $1784 \mathrm{r}$. Zug był też odpowiedzialny za inne przedsięwzięcia na terenie jurydyki między innymi za projekt zboru dysydentów na Lesznie oraz przebudowy dawnego dworu Leszczyńskich przy ulicy Rymarskiej, wówczas pełniącego funkcję rezydencji Potockich (Bobrowski 54; Kwiatkowski 121-122, 158-159, 205-207; Wątroba 109-110).
} 
Giovani Battista Gisleni wykonał też dwie wersje projektów szpitala bonifratrów. W 1650 r. Bracia Miłosierdzia zostali sprowadzeni z Krakowa przez Bogusława Leszczyńskiego (Bartoszewicz 233; Bartczakowa i Sokołowska 405; Łobozek 13). Na tej podstawie można potwierdzić datowanie szkiców na czas między 1650 a 1655 r., skłaniając się jednak bliżej samej połowy XVII stulecia. Podskarbi wielki koronny przekazał grunt pod budowę na terenie swojej jurydyki kościoła $z$ klasztorem i infirmerią oraz darował zakonnikom 1000 talarów - równowartość 3000 złp (Bartczakowa i Sokołowska 405; Łobozek 12-13) $)^{12}$. Wsparcia finansowego udzielili także przyszły biskup kijowski Tomasz Ujejski (10 000 złp) oraz Tomasz Rupnin (4000 złp) (Bartczakowa i Sokołowska 405; Pietrzkiewicz 65; Czajkowski 159). Bonifratrzy prowadzili na Lesznie szpital z ośmioma łóżkami dla ubogich i chorych umysłowo (Karpiński 274; Bogucka 105; Lileyko, Życie codzienne 231; Łobozek 92; Marek i Persa 69; Czajkowski 159). Założenie klasztorne było położone $\mathrm{w}$ północnej pierzei głównego traktu jurydyki, na posesji noszącej później nr hip. 686. Zakonnicy przebywali w tym miejscu zaledwie kilkanaście lat - Jan Andrzej Morsztyn przekazał im wówczas dwór na terenie starostwa warszawskiego, na obszarze dzisiejszego Ogrodu Saskiego (Czajkowski 160; Karpiński 274) ${ }^{13}$, odziedziczony po bracie Tobiaszu. W testamencie zmarłego znalazł się zarazem zapis związany z wolą przekazania 30000 złp na fundację nowego założenia klasztornego Braci Miłosierdzia (WiMBPwB, sygn. Rkp 1226/35 III.). W 1666 r. biskup poznański Stefan Wierzbowski udzielił zgody na relokację ${ }^{14}$. Stary konwent miał odtąd pełnić funkcję podmiejskiego folwarku bonifratrów (Bartczakowa i Sokołowska 408).

Projekty drewnianych szpitali na Lesznie ukazują formy dość charakterystyczne dla Gisleniego. Szczególnie interesująco prezentuje się jedna z wersji (il. 7). Widoczny na niej parterowy budynek na rzucie wydłużonego prostokąta, nakryty wysokim dachem, ma naroża podkreślone boniami i okna ujęte uszakowymi obramieniami. Główną dominantę stanowi ośmiokątna wieża, usytuowana na osi dłuższego boku i mieszcząca kaplicę (Tkaczyk 453). Kopułę na bębnie z półkolistymi okienkami wieńczy krzyż. Wieża tworzy

\footnotetext{
${ }^{12}$ Zabudowania wzniesiono na posesji noszącej później nr hip. 686.

${ }^{13}$ W 1725 r. biegnąca przy klasztorze ulica uzyskała nazwę Królewskiej. Zabudowania klasztorne wzniesione na terenie dawnej posesji Morsztyna zostały udokumentowane na planie Warszawy z 1726 r. (Bartczakowa i Sokołowska 406, il. 1).

${ }^{14}$ Jako że na terenie klasztoru było miejsce przeznaczone na pochówki, kościół miał odtąd pełnić funkcję kaplicy cmentarnej. Natomiast już w 1669 r. nakazano likwidację nekropolii (Bartczakowa i Sokołowska 408).
} 
od frontu trójboczny ryzalit, z głównym wejściem do budynku na osi. Rzut przyziemia uwidacznia, że właśnie przestrzeń sakralna jest głównym akcentem wnętrza, zaburzającym regularność podziału na dwa trakty (il. 8). Kaplica z pewnością miała też być najlepiej doświetloną przestrzenią - ponad drzwiami zaplanowano bogato dekorowane, czworokątne okno, „skośne” zaś ściany miały mieścić monumentalne, półkoliście zamknięte otwory okienne. Na planie szpitala widać również dwa kolejne okna, znajdujące się w bocznych ścianach, usytuowanych z pewnością ponad dachem budowli. Do wnętrza kaplicy symetrycznie przylegają dwie sale, każda z pięcioma łóżkami dla chorych, ustawionymi w jednym rzędzie, przy ścianie naprzeciw linii okien. $\mathrm{W}$ drugim, tylnym trakcie znajduje się położona za kaplicą kuchnia, zapewne pełniąca jednocześnie funkcję refektarza ${ }^{15}$. Po obu stronach przylegają do niej dwa pomieszczenia przeznaczone dla opiekunów chorych oraz pełniące funkcje użytkowe (il. 9).

Druga koncepcja infirmerii bonifratrów różni się zarówno formą architektoniczną, jak i dyspozycją wnętrz. Bryła jest znacznie bardziej zwarta (il. 10). Środkowa partia budowli (obejmująca trzy z dziewięciu osi fasady) została wypiętrzona, ujęta podziałem ramowym i zwieńczona trójkątnym frontonem - sięgającym wysokością kalenicy stromego dachu szpitala, nad którym góruje krzyż. Główne wejście ujęto obramieniem dźwigającym belkowanie z trójkątnym naczółkiem. Drzwi flankują smukłe, duże okna w profilowanych obramieniach. W zwieńczeniu, w polu tympanonu widnieje dekoracja heraldyczna. Wbrew pierwszemu wrażeniu ryzalit jest jedynie pozorny - spojrzenie na rzut ujawnia, że centralna, wyższa część budowli nie występuje przed lico muru. Wnętrza mają układ dwutraktowy (il. 11). Główne wejście prowadzi do kaplicy, po obu jej bokach znajdują się sale dla pacjentów. Na tyłach, na osi obiektu zaplanowano kuchnię flankowaną przez pomieszczenia przeznaczone dla opiekunów oraz do pełnienia funkcji gospodarczych (i1. 12). Proporcje boków murów obwodowych wynoszą w przybliżeniu 4:2,5 - a nie jak przy omówionej wcześniej, pierwszej propozycji szpitala 4:1,375 - i w efekcie sale dla chorych zbliżone są do kwadratu. Uwarunkowało to odmienny układ łóżek - po trzy są ustawione pomiędzy oknami, po dwa zaś przy przeciwległej ścianie. Porównanie obu koncepcji infirmerii wskazuje nie tylko różnice w rzeźbiarskości i złożoności brył, ale też w stopniu szczegółowości rysunków. W przypadku projektu z ośmioboczną wieżą widok elewacji został przedstawiony bardziej precy-

\footnotetext{
${ }^{15}$ Modelowy schemat dyspozycji wnętrz szpitali klasztornych w XVII stuleciu został zaprezentowany w artykule Pawła Tkaczyka (451-452).
} 
zyjnie, zastosowano efekty światłocieniowe, zaciemniono wnętrza otworów okiennych oraz drzwi. Na rzucie widoczna jest skala z podziałką liczbową. Poszczególne pomiary zostały też naniesione bezpośrednio w każdym z pomieszczeń. Fasada szpitala $\mathrm{z}$ trójkątnym przyczółkiem została przedstawiona $\mathrm{w}$ formie bardziej szkicowej, z konturami pozbawionymi walorów plastycznych. Wnętrza okien nie zostały zamalowane, efekt cienia występuje prawie wyłącznie we fragmencie dachu. Ponadto widoczny jest brak dokładności w zachowaniu proporcji okien, równoległego przebiegu linii (zwłaszcza obramień drzwi i okien), czy w kulach wieńczących kalenicę, gdzie początek i koniec kreski kreślącej okrąg rozmijają się. Linie sprawiają wrażenie bardziej rozedrganych, co jednak po części może wynikać z właściwości zastosowanego papieru. Schematyzm cechuje też rzut przyziemia - u dołu umieszczono jedynie skalę niemianowaną. Również we wnętrzu szpitala nie oznaczono żadnych wartości liczbowych ${ }^{16}$.

Pytaniem otwartym pozostaje realizacja którejś z powyższych koncepcji na terenie klasztoru lesznieńskich bonifratrów. W szpitalu pierwotnie miało się znajdować osiem łóżek (Karpiński 274; Marek i Persa 69), podczas gdy na obu wersjach szkiców drezdeńskich oznaczono ich dziesięć. Zmiana w zagospodarowaniu wnętrza nie musiała jednak oznaczać rezygnacji z zaproponowanych form architektonicznych. Niewykluczone, że jeden z projektów został przynajmniej częściowo wykorzystany.

Dla jurydyki Leszczyńskich została też zaprojektowana przykładowa zabudowa ${ }^{17}$. Jeden $\mathrm{z}$ rysunków $\mathrm{z}$ notatnika Gisleniego prezentuje jej fasadę (il. 13). Obiekt został pomyślany jako parterowy z użytkowym poddaszem. Od frontu dostawiono podcienia kolumnowe. W przyziemiu elewacji jest widocznych sześć osi, które tworzą dwa lustrzane moduły, złożone z półkoliście zamkniętych otworów wejściowych, flankowanych przez okna w profilowanych obramieniach. Poszczególne osie oddzielają pilastry podtrzymujące gzyms. W zaskakujący sposób prezentuje się nadbudówka. W części centralnej umieszczono trójkątny szczyt z dwoma oknami. Projekt wskazuje, że występujące przy skrajach budowli, „przerwane” w połowie szczyty stwarzają możliwość powielania schematu i dostawienia kolejnych modułów. Horyzontalizm budowli staje się przez to jeszcze silniejszy. Sąsiadujące

\footnotetext{
${ }^{16}$ Analogiczna szkicowość cechuje część rysunków Gisleniego z drezeńskiego notatnika wśród nich projekty Pałacu Biskupów w Krakowie, wykonane dla Jana Gembickiego (Staatliche Kunstsammlungen Dresden, Kupferstich-Kabinett, nr inw. Ca 67/15r, a także: Ca 67/45r. Druga z kart była reprodukowana w artykule: Mossakowski, „Pałac Biskupi” 137, il. 1).

${ }^{17}$ Jak wspomniano na wstępie, szkic interpretowano dotąd jako projekt domów dla jurydyki Grzybów (Putkowska 27) lub propozycję austerii (por. przyp. 3).
} 
z sobą domy miały mieć układy o lustrzanym odbiciu. Główne wejście prowadzi w nich do sieni połączonej ze stajnią i wiodącej do kuchni ${ }^{18}$ oraz izb małych od frontu oraz większych w głębi ${ }^{19}$. Brakuje potwierdzenia, że zabudowa podcieniowa zaproponowana przez Gisleniego doczekała się realizacji. Jest jednak ciekawą próbą rozwiązania kwestii urbanistycznych na terenie jurydyki.

Zakres realizacji projektów Giovanniego Battisty Gisleniego budzi wątpliwości. W pełni wykorzystano jedynie koncepcję rezydencji Bogusława Leszczyńskiego. Rysunki przechowywane w stolicy Saksonii w większości pozostały na papierze, co mogło być wynikiem kilku czynników - przedsięwzięcia nie ułatwił chociażby „potop szwedzki”. Na docenienie zasługuje jednak zaangażowanie do prac wybitnego architekta dworskiego. Należy zarazem podkreślić ważną rolę projektów urbanistycznych jako przeznaczonych dla jurydyki magnackiej i związanych $\mathrm{z}$ chęcią stworzenia spójnego programu architektonicznego dla najważniejszych obiektów.

Założenie Leszna było działaniem prekursorskim. Prywatne zespoły urbanistyczne poza murami Starej Warszawy powstawały od średniowiecza. Pierwsze, takie jak Świętojerska i założona w 1402 r. Dziekanka, podlegały władzy duchownej. Istnienie jurydyk zostało usankcjonowane prawnie w 1559 r. Mimo to przez kolejne stulecie nie zdecydowano się na założenie żadnej o charakterze świeckim. Tworzono za to nowe ośrodki kościelne - Zadzikowską (zw. Kapitulną) w 1638 r. (Lileyko, Zycie codzienne 27), a trzy lata później Skaryszew, należący do kapituły płockiej (Gawryszewski 15). Erygowanie przez Leszczyńskich w 1648 r. Nowego Leszna było momentem przełomowym w rozwoju urbanistycznym okolic Starego Miasta - warunkującym zarazem kształtowanie sieci ulic i zabudowy w kolejnych stuleciach (Sawicki, „Kształty warszawskich ulic” passim). Leszno zapoczątkowało tworzenie jurydyk świeckich. Już dwa lata później, w 1650 r., powstał Grzybów Jana Grzybowskiego (Wyrobisz 18). Tendencja rozpowszechniła się w kolejnych dekadach - między innymi ród magnacki Wielopolskich w 1693 r. założył Wielopole. Również w kolejnym stuleciu nie mogło zabraknąć jurydyk należących do elit politycznych. Wspomnieć wystarczy Ordynacką Jana Jakuba Zamoyskiego, założoną w 1739 r. (Drozdowski, Sołtan i Zahorski 86), czy

\footnotetext{
${ }^{18}$ Kuchnia miała być zlokalizowana w środku budynku i w efekcie pozbawiona okien. Wedle szkicu komin nad paleniskami dwóch sąsiadujących domów miał być wyprowadzony wysoko ponad dach - widoczny jest więc na projekcie elewacji.

${ }^{19}$ Próbę interpretacji funkcji poszczególnych pomieszczeń przedstawiła przed trzydziestu laty Jolanta Putkowska (27-28).
} 
powstałe w 1757 r. Bielino marszałka wielkiego koronnego, Franciszka Bielińskiego, zaprojektowane przez jednego z najważniejszych architektów lat 50. XVIII wieku - Jakuba Fontanę (Sito 267).

Rysunki Gisleniego obrazują ambitny sposób myślenia o rozwoju przestrzennym i funkcjonalnym jurydyk oraz architekturze pojedynczych obiektów, które miały stać się wizytówką założyciela, podkreślającą jego rolę polityczną i obecność w Warszawie jako miejscu pobytu króla. Jednocześnie omówione szkice sygnalizują szerszą problematykę, związaną z aktywnością fundatorską rodu Leszczyńskich w XVII wieku i rozwojem urbanistycznym stołecznych przedmieść. Drezdeńskie projekty pozostają więc godnym dostrzeżenia świadectwem próby ukształtowania architektury prywatnego miasteczka magnackiego, którym było warszawskie Leszno.

\section{BIBLIOGRAFIA}

ARCHIWALIA

Archiwum Główne Akt Dawnych [AGAD], Zbiór dokumentów pergaminowych, August III, król polski, potwierdza i transsumuje przywilej Augusta II [Warszawa, 1699.04.05/, w którym transsumuje przywilej Jana III [Kraków, 1676 r.], w którym przywilej Bogusława z Leszna Leszczyńskiego [Warszawa, 1648.01.08], erygujacy miasto Leszno pod Warszawa, potwierdzony i rozszerzony przez jana Kazimierza [Warszawa, 1654.06.20], 1745, sygn. $1 / 1 / 0 /-/ 1700$.

Archiwum Główne Akt Dawnych [AGAD], Zbiór dokumentów pergaminowych, Bogusław na Lesznie Leszczyński, starosta generalny wielkopolski, nadaje przywilej fundacyjny posiadłości swej Leszno na przedmieściu Warszawy, 1648, sygn. 1/1/0/-/1696.

Archiwum Główne Akt Dawnych [AGAD], Zbiór dokumentów pergaminowych, Jan III, król polski, potwierdza i transsumuje akt fundacyjny Bogusława na Lesznie Leszczyńskiego dla Leszna, przedmieścia Warszawy z 8 I 1648 r. oraz transsumuje $i$ rozszerza swoimi klauzulami potwierdzenie Jana Kazimierza [Warszawa, 1654.06.20], 1676, sygn. 1/1/0/1698.

Archiwum Główne Akt Dawnych [AGAD], Zbiór dokumentów pergaminowych, Michat, król polski, potwierdza i transsumuje akt fundacyjny Bogusława na Lesznie Leszczyńskiego dla Leszna przedmieścia Warszawy [Warszawa, 1648.01.08] oraz potwierdzenie tegoż $i$ transsumpt Jana Kazimierza z 20 VI 1654 r., 1669, sygn. 1/1/0/-/1697.

Wojewódzka i Miejska Biblioteka Publiczna w Bydgoszczy, Stefan Wierzbowski, biskup poznański potwierdza zapis testamentowy Tobiasza Morsztyna z Raciborska, towczego koronnego. W testamencie z dn. 15.X.1664 r. zapisuje 30.000 ztp na budowe szpitala przy kościele Bonifratrów w Warszawie, sygn. Rkp 1226/35 III. 


\section{OPRACOWANIA}

Bania, Zbigniew. „Architektura”. Sztuka Polska, t. IV: Wczesny i dojrzaly barok, red. Jerzy Kowalczyk, Arkady, 2013, ss. 13-161.

Bartczakowa, Aldona, i Alina Sokołowska. „Klasztor Bonifratrów w Warszawie”. Biuletyn Historii Sztuki, nr 3, 1967, ss. 405-416.

Bartoszewicz, Agnieszka, i Henryk Bartoszewicz. „Kartografia miast Korony Królestwa Polskiego do 1795 r. Stan zachowania miejskich map wielkoskalowych, rozmieszczenie ich w zbiorach polskich i zagranicznych oraz potrzeby i perspektywy badawcze. Projekt monografii". Archeion, 2017, ss. 275-325.

Bartoszewicz, Agnieszka, i Henryk Bartoszewicz. „Obraz kartograficzny terytoriów przedmiejskich Warszawy w XVII-XVIII wieku”. Rocznik Warszawski, t. 37, 2009/2010, ss. 41-92.

Bartoszewicz, Julian. Kościoły warszawskie rzymsko-katolickie opisane pod względem historycznym. Drukarnia S. Olgerbranda w Warszawie, 1855.

Bernatowicz, Tadeusz. Mitra i buława: królewskie ambicje ksiąząt w sztuce Rzeczypospolitej szlacheckiej (1697-1763). Wydawnictwa Uniwersytetu Warszawskiego, 2011.

Bernatowicz, Tadeusz. „Nowe spojrzenie na pałac Saski”. Spotkania z Zabytkami, z. 31, 2007, ss. 14-16.

Bobrowski, Zbigniew. Studia i Materiaty do teorii i historii architektury i urbanistyki III. Budynki użyteczności publicznej w Polsce wieku oświecenia. Polska Akademia Nauk, 1961.

Bogucka, Maria. „Dzieje Warszawy 1526-1655”. Warszawa w latach 1526-1795, red. Andrzej Zahorski, Państwowe Wydawnictwo Naukowe, 1984, ss. 7-177.

Ciara, Stefan. Senatorowie i dygnitarze koronni w drugiej połowie XVII wieku. Zakład Narodowy im. Ossolińskich, 1990.

Czajkowski, Marcin. „Instytucjonalna opieka nad chorymi psychicznie w Warszawie w drugiej połowie XVIII wieku”. Wśród córek Eskulapa. Szkice z dziejów medycyny i higieny w Rzeczypospolitej XVI-XVIII wieku. Część II, red. Andrzej Karpiński, Wydawnictwo DiG, 2015, ss. 143-217.

Drozdowski, Marian, Tadeusz Sołtan i Andrzej Zahorski. Historia Warszawy. Wydawnictwo Bellona, 2017.

Dworzaczek, Włodzimierz. „Leszczyński Bogusław (ok. 1612-1659)”. Polski Słownik Biograficzny, red. Emanuel Rostworowski, t. XVII, Zakład Narodowy im. Ossolińskich, 1972, ss. 107-111.

Forycki, Maciej. Stanisław Leszczyński. Wydawnictwo Poznańskie, 2016.

Gawryszewski, Andrzej. Ludność Warszawy w XX wieku. Polska Akademia Nauk, 2009.

Główka, Dariusz, i Elżbieta Mazur. „Dzieje siedziby Jacobsona w Warszawie w drugiej połowie XVIII i na początku XIX w.”. Kwartalnik Historii Kultury Materialnej, z. 2, 2019, ss. 223-232.

Greco, Gianpasquale. „Neque hic vivus, neque illuc mortuus: la tomba di Giovan Battista Gisleni e il suo doppio a stampa". Storia dell'arte, nr 40, 2015, ss. 83-96.

Hundert, Zbigniew, i Jacek Żukowski, redaktorzy. Świat polskich Wazów. Przestrzeń - ludzie sztuka, Zamek Królewski w Warszawie - Muzeum, 2019.

Kaczorowski, Włodzimierz. „Wolna elekcja «viritim» i koronacja Władysława IV”. Świat polskich Wazów: eseje, red. Zbigniew Hundert i Jacek Żukowski, Zamek Królewski w Warszawie - Muzeum, 2019, ss. 219-237. 
Kapustka, Mateusz. „Der Körper des Künstlers im Kampf der Künste. Zur Medienkritik im Grabmal von Giambattista Gisleni (+ 1672) in Santa Maria del Popolo in Rom”. Künstlergrabmäler. Genese - Typologie - Intention - Metamorphosen, red. Markwart Herzog, Birgit Ulrike Münch i Andreas Tacke, Michael Imhof Verlag 2011, ss. 151-165.

Karpiński, Andrzej. Pauperes. O mieszkańcach Warszawy XVI i XVII wieku. Państwowe Wydawnictwo Naukowe, 1983.

Karwowski, Stanisław. Leszczyńscy herbu Wieniawa. Związkowa Drukarnia we Lwowie, 1916.

Konarski, Kazimierz. Warszawa w pierwszym jej stotecznym okresie. Państwowy Instytut Wydawniczy, 1970.

Kret, Wojciech. „Theatrum in exequiis Karola Ferdynanda Wazy na tle twórczości Giovanniego Battisty Gisleniego". Rocznik Warszawski, t. 13, 1975, ss. 41-66.

Kriegseisen, Wojciech. „Ewangelicy reformowani jako czynnik w procesie modernizacji w Rzeczypospolitej szlacheckiej w drugiej połowie XVI w. i w Warszawie epoki stanisławowskiej”. Rocznik Teologiczny, z. 1/2, 2009, ss. 291-307.

Kwiatkowski, Marek. Szymon Bogumit Zug. Architekt polskiego oświecenia. Państwowe Wydawnictwo Naukowe, 1971.

Lileyko, Jerzy. „Władysławowski Pokój Marmurowy na Zamku Królewskim w Warszawie i jego twórcy - Giovanni Battista Gisleni i Peter Danckers de Rij”. Biuletyn Historii Sztuki, nr 1, 1975, ss. 13-31.

Lileyko, Jerzy. Życie codzienne w Warszawie za Wazów. Państwowy Instytut Wydawniczy, 1984.

Łobozek, Marcin Maksymilian. Bonifratrzy w Warszawie (1650-2000). Klasztor OO. Bonifratrów w Katowicach, 2000.

Małcużyński, Witold. Rozwój terytorialny miasta Warszawy. Drukarnia E. Lubowskiego w Warszawie, 1900.

Marek, Anna, Jacek Persa i Marek Wichrowski. Warszawska uczelnia medyczna $w$ ikonografii i fotografii. Warszawski Uniwersytet Medyczny, 2009.

Miks-Rudkowska, Nina. „Kapela królewska Wazów w rysunku G. B. Gisleniego, architekta i muzyka królewskiego". Sarmatia artistica. Księga pamiątkowa ku czci profesora Władysława Tomkiewicza, red. Jan Białostocki, Państwowe Wydawnictwo Naukowe, 1968, ss. 10-105.

Miks-Rudkowska, Nina. „Niektóre projekty dekoracji scenograficznej Giovanniego Battisty Gisleniego na dworze Wazów”. Opera w dawnej Polsce na dworze Władystawa IV i królów saskich: studia i materiały, red. Julian Lewański, Zakład Narodowy im. Ossolińskich, 1973, ss. 9-24.

Miks-Rudkowska, Nina. „Pałac Bogusława Leszczyńskiego w Warszawie i jego twórca G.B. Gisleni”. Biuletyn Historii Sztuki, nr 2/3, 1984, ss. 187-202.

Miks-Rudkowska, Nina. „Theatrum in exequiis Karola Ferdynanda Wazy. Z badań nad twórczością G.B. Gisleniego". Biuletyn Historii Sztuki, nr 4, 1968, ss. 419-434.

Miks-Rudkowska, Nina. „Zbiór rysunków G.B. Gisleniego, architekta XVII wieku, w Sir John Soane's Museum w Londynie". Biuletyn Historii Sztuki, nr 4, 1961, ss. 328-339.

Miłobędzki, Adam. Architektura polska XVII wieku. Państwowe Wydawnictwo Naukowe, 1980.

Mossakowski, Stanisław. „Galeria przy Villa Regia w Warszawie projektu G.B. Gisleniego”. Biuletyn Historii Sztuki, nr 1/2, 1995, ss. 37-54.

Mossakowski, Stanisław. „Gli anni romani di Giovanni Battista Gisleni”. Biuletyn Historii Sztuki, nr 1/2, 2009, ss. 35-56.

Mossakowski, Stanisław. „Pałac Biskupi w Krakowie a projekty Giovanniego Battisty Gisleniego". Roczniki Sztuki Śląskiej, 1999, ss. 137-145. 
Mossakowski, Stanisław. „Rzymskie lata Giovanniego Battisty Gisleniego”. Polska i Europa $w$ dobie nowożytnej. Prace naukowe dedykowane Profesorowi Juliuszowi A. Chrościckiemu, red. Tadeusz Bernatowicz, Zamek Królewski w Warszawie - Muzeum, 2009, ss. 535-549.

Mossakowski, Stanisław. „Uroczystości wawelskie w styczniu 1649 roku a projekty Giovanniego Battisty Gisleniego". Orbis Polonus. Studia z historii sztuki XVII-XVIII wieku. Wydawnictwo DiG, 2002, ss. 85-141.

Osiecka-Samsonowicz, Hanna. „Gisleni (Ghisleni) Giovanni Battista”. Stownik architektów i budowniczych środowiska warszawskiego XV-XVIII wieku, red. Jakub Sito, Hanna Osiecka-Samsonowicz i Paweł Migasiewicz, Polska Akademia Nauk, 2016, ss. 165-181.

Pietrzkiewicz, Iwona, „Miser res sacra”. Bonifratrzy $w$ dawnej Rzeczypospolitej. Bikstudio, 2009.

Putkowska, Jolanta. Architektura Warszawy XVII wieku. Wydawnictwo Naukowe PWN, 1991.

Rejman, Zofia. „Jurydyka Leszno w czasach Stanisława Augusta Poniatowskiego”. Rocznik Warszawski, t. 18, 1985, ss. 61-119.

Resmini, Monica. „Giovanni Battista Gisleni”. Le arti del disegno. Architettura, ornato, figura, red. Stefano L'Occaso i Maria Cristina Loi, Il Rio, 2017, ss. 38-49.

Sawicki, Jacek. „Kształty warszawskich ulic a kartografia”. Wnętrze warszawskiej ulicy. Materiały sesji naukowej. Warszawa, 5-6 kwietnia 2001 roku 2002, red. Bożena Wierzbicka, Towarzystwo Opieki nad Zabytkami, 2002, ss. 209-219.

Sawicki, Tymoteusz. „Jurydyki i ratusze Warszawy”. Kronika Warszawy, z. 11, 1925, ss. 2-8.

Sito, Jakub. Wielkie warsztaty rzeźbiarskie Warszawy doby saskiej: modele kariery, formacja artystyczna, organizacja produkcji. Muzeum Pałacu Króla Jana III w Wilanowie, 2013.

Szwankowski, Eugeniusz. Warszawa: rozwój urbanistyczny i architektoniczny. Państwowe Wydawnictwa Techniczne, 1952.

Tkaczyk, Paweł. „Architektura wybranych kościołów szpitalnych XVII wieku”. Liturgia Sacra. Liturgia-Musica-Ars, t. 14, nr 2, 2008, ss. 449-471.

Tygielski, Wojciech. „Czy potrafimy skonstruować model kariery Włocha w siedemnastowiecznej Rzeczypospolitej?”. Czasy Nowożytne, t. 31, 2018, ss. 73-88.

Wardzyński, Michał. „Rezydencje królewskie Wazów - europejskie inspiracje architektury i rzeźby”. Świat polskich Wazów: eseje, red. Zbigniew Hundert i Jacek Żukowski, Zamek Królewski w Warszawie - Muzeum, 2019, ss. 265-273.

Wardzyński, Michał. „Sztuka nowożytna na Mazowszu, Zarys problematyki”. Dzieje Mazowsza. T. 2. Lata 1527-1795, red. Jan Tyszkiewicz, Akademia Humanistyczna im. Aleksandra Gieysztora, 2015, ss. 629-731.

Wątroba, Przemysław. „Szymon Bogumił Zug (1733-1807) - architekt dworu saskiego w Warszawie”. Elizeum - podziemny salon księcia, Dla przyjaciót i pięknych pań, red. Karol Guttmejer, Miasto Stołeczne Warszawa, 2016, ss. 103-118.

Wegner, Jan, „Warszawa w czasie najazdu szwedzkiego 1655-1657”. Polska w okresie drugiej wojny pótnocnej, 1655-1660, red. Kazimierz Lepszy, Państwowe Wydawnictwo Naukowe, 1957, ss. 231-259.

Wyrobisz, Andrzej. „Nazwy ulic, placów i dzielnic w miastach polskich: nośniki informacji źródła historyczne - zabytki kultury", Przeglad Historyczny, nr 4, 1999, s. 511-589.

Żukowski, Jacek. Żądza chwały. Władysław IV Waza w ikonografii performatywnej, Muzeum Pałacu Króla Jana III w Wilanowie, 2018. 


\section{PROJEKTY GIOVANNIEGO BATTISTY GISLENIEGO \\ DLA WARSZAWSKIEJ JURYDYKI LESZCZYŃSKICH \\ W ZBIORACH DREZDEŃSKICH}

\section{Streszczenie}

W kolekcji Staatliche Kunstsammlungen w Dreźnie znajdują się projekty autorstwa Giovanniego Battisty Gisleniego dla warszawskiej jurydyki Bogusława Leszczyńskiego, datowane na lata 1650-55. Leszno (Nowe Leszno), założone na prawie chełmińskim w 1648 r., było pierwszą świecką jurydyką w Warszawie. W artykule przybliżone zostały formy architektoniczne poszczególnych obiektów, zaproponowane przez Gisleniego. Ratusz zaprojektowano jako budynek murowany, dwukondygnacyjny, na planie prostokąta, z ryzalitem wieżowym na osi. Szczególnie interesująco prezentują się dwie wersje drewnianego szpitala bonifratrów, którzy zostali sprowadzeni z Krakowa przez założyciela Leszna. Warto podkreślić, że Gisleni zaprojektował również rezydencję Bogusława Leszczyńskiego, wzniesioną od strony ulicy Rymarskiej. Układ zabudowy Nowego Leszna silnie wpłynął na rozwój urbanistyczny tej części Warszawy. Omówione w artykule projekty są zarówno dokumentem związanym z historią jurydyki, jak i świadectwem ambicji jej właściciela.

Słowa kluczowe: Warszawa; architektura; XVII wiek; Giovanni Battista Gisleni; Bogusław Leszczyński; bonifratrzy.

\section{GIOVANNI BATTISTA GISLENI'S DESIGNS FOR THE LESZCZYŃSKI FAMILY'S JURYDYKA IN WARSAW, AS HELD IN THE DRESDEN COLLECTION}

\section{S u m m a ry}

The collection of the Staatliche Kunstsammlungen Dresden includes designs by Giovanni Battista Gisleni for the Warsaw jurydyka of Bogusław Leszczyński, dated 1650-1655. Leszno (Nowe Leszno), established under the Kulm (Chełmno) Law in 1648, was the first secular jury$d y k a$ in Warsaw. This article presents the architectural forms of individual buildings, as proposed by Gisleni. The town hall was designed as a two-storey brick building on a rectangular plan with an avant-corps on the axis. Of particular interest are two versions of the wooden hospital of the Brothers Hospitallers of John of God, who were brought from Kraków by the founder of Leszno. It is worth noting that Gisleni also designed Bogusław Leszczyński's residence, which was built facing Rymarska Street. The layout of the buildings in Nowe Leszno strongly influenced the urban development of this part of Warsaw. The designs discussed in the article both document the history of the jurydyka and testify to Bogusław Leszczyński's ambitions.

Keywords: Warsaw; architecture; 17th century; Giovanni Battista Gisleni; Bogusław Leszczyński; Brothers Hospitallers of Saint John of God. 


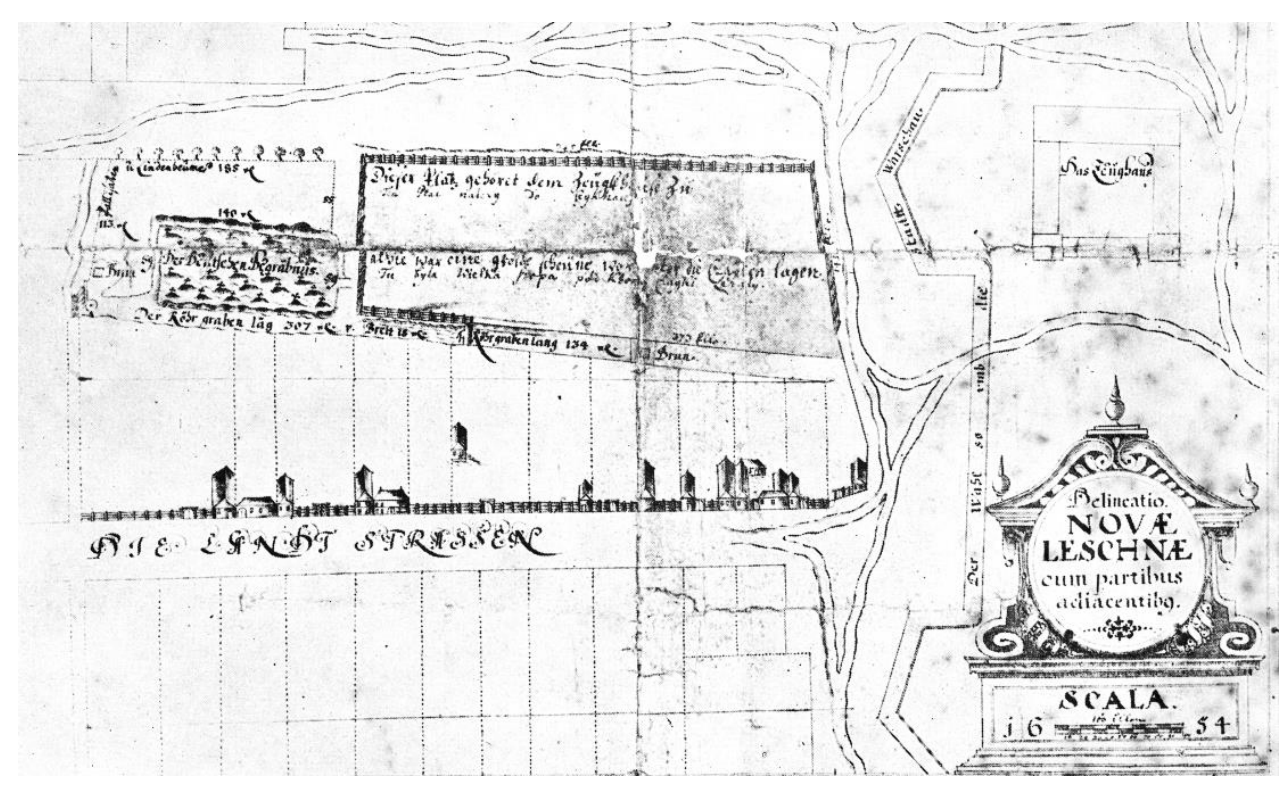

1. S. Englert, Delineatio Novae Leschnae cum partibus adiacentibus, 1654, fot. Instytut Sztuki PAN. 


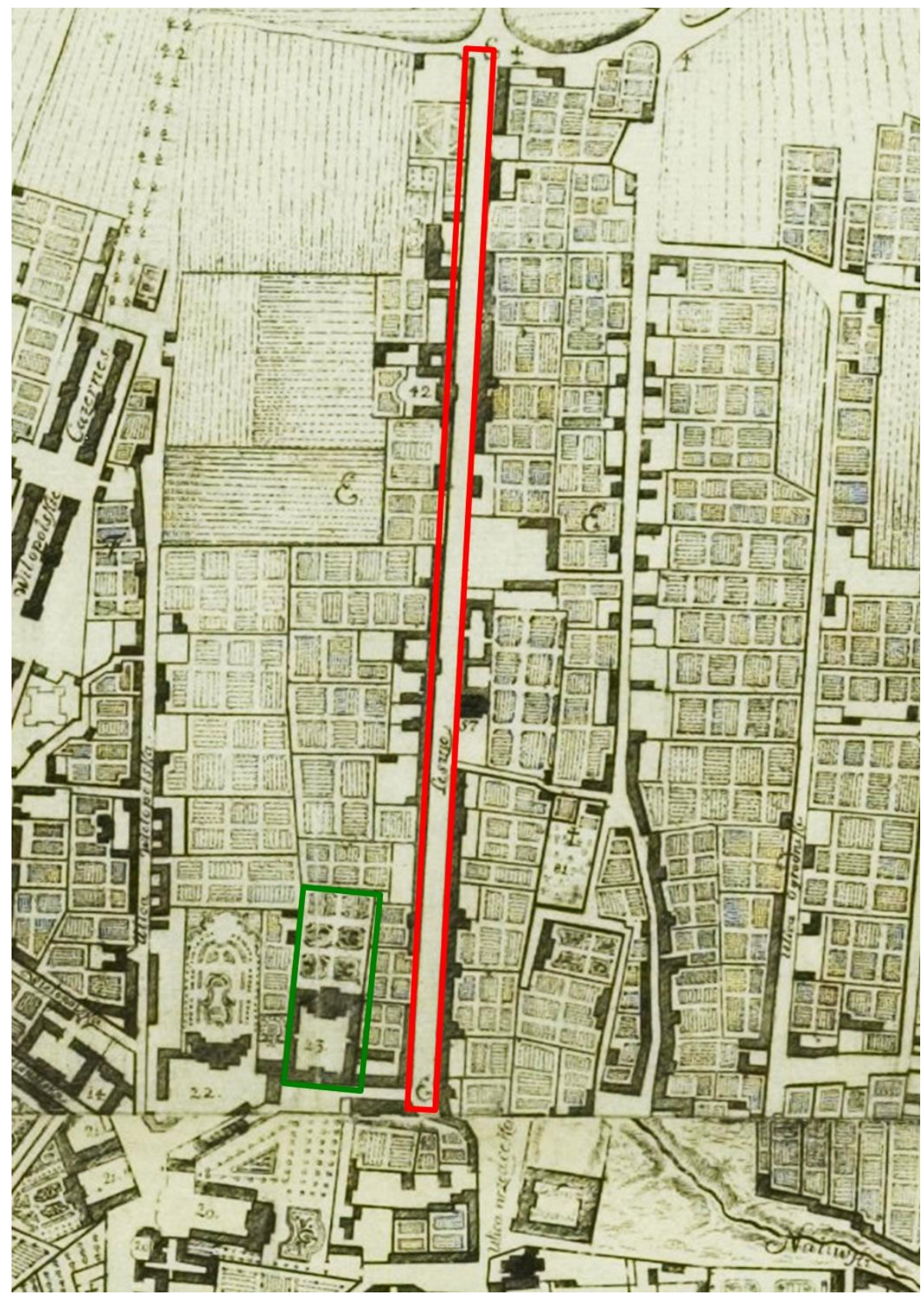

2. Główny trakt jurydyki (ulica Leszno) oraz pałac przy ulicy Rymarskiej w 2. połowie XVIII wieku, oznaczenia Alina Barczyk

(na podstawie P. Ricaud de Tirregaille, Plan de la ville de Varsovie, 1762, Biblioteka Narodowa w Warszawie, fot. domena publiczna) 


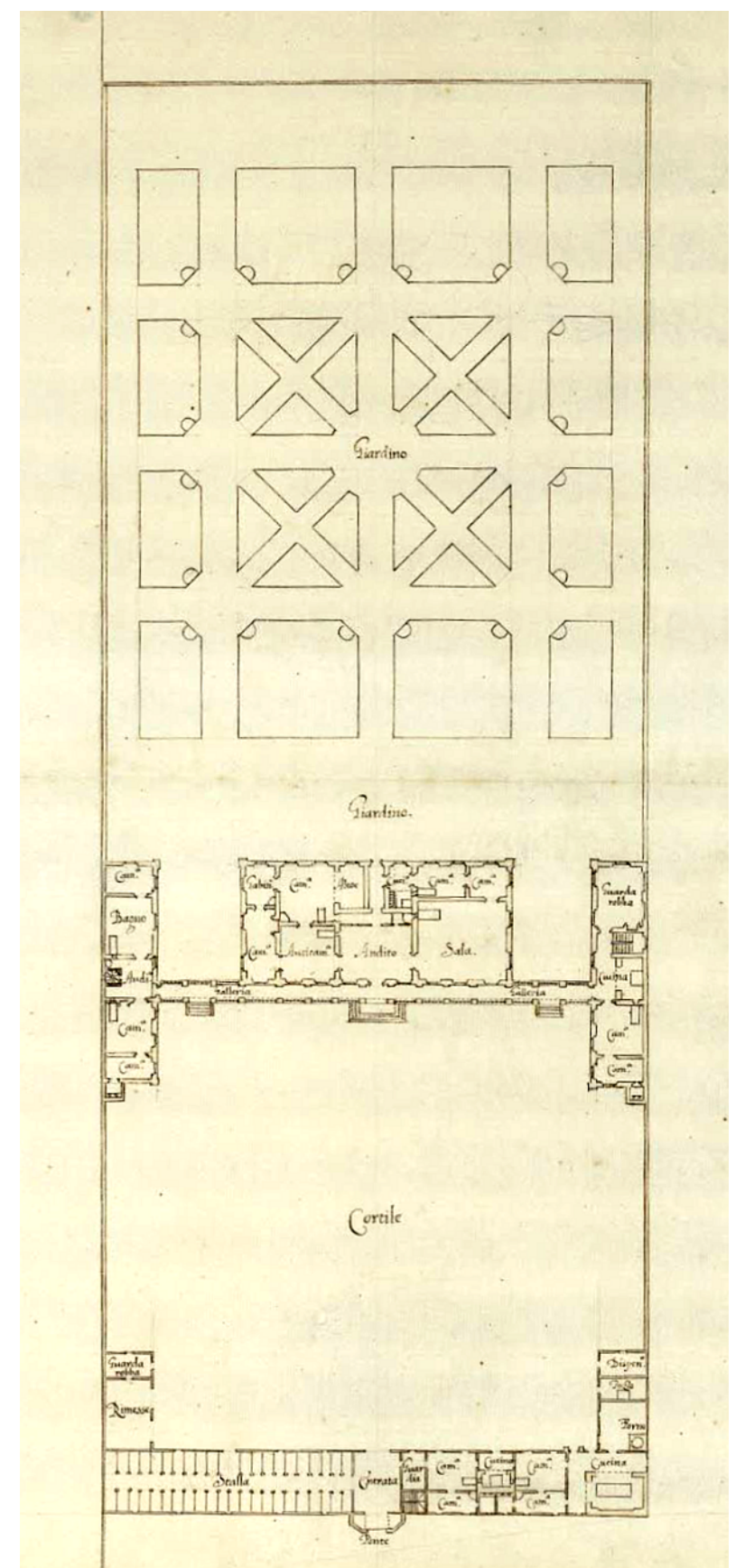

3. G.B. Gisleni, Projekt rezydencji Bogusława Leszczyńskiego na Lesznie, ok. 1650, Raccolte Grafiche e Fotografiche del Castello Sforzesco. Gabinetto dei Disegni, Milano, fot. domena publiczna 


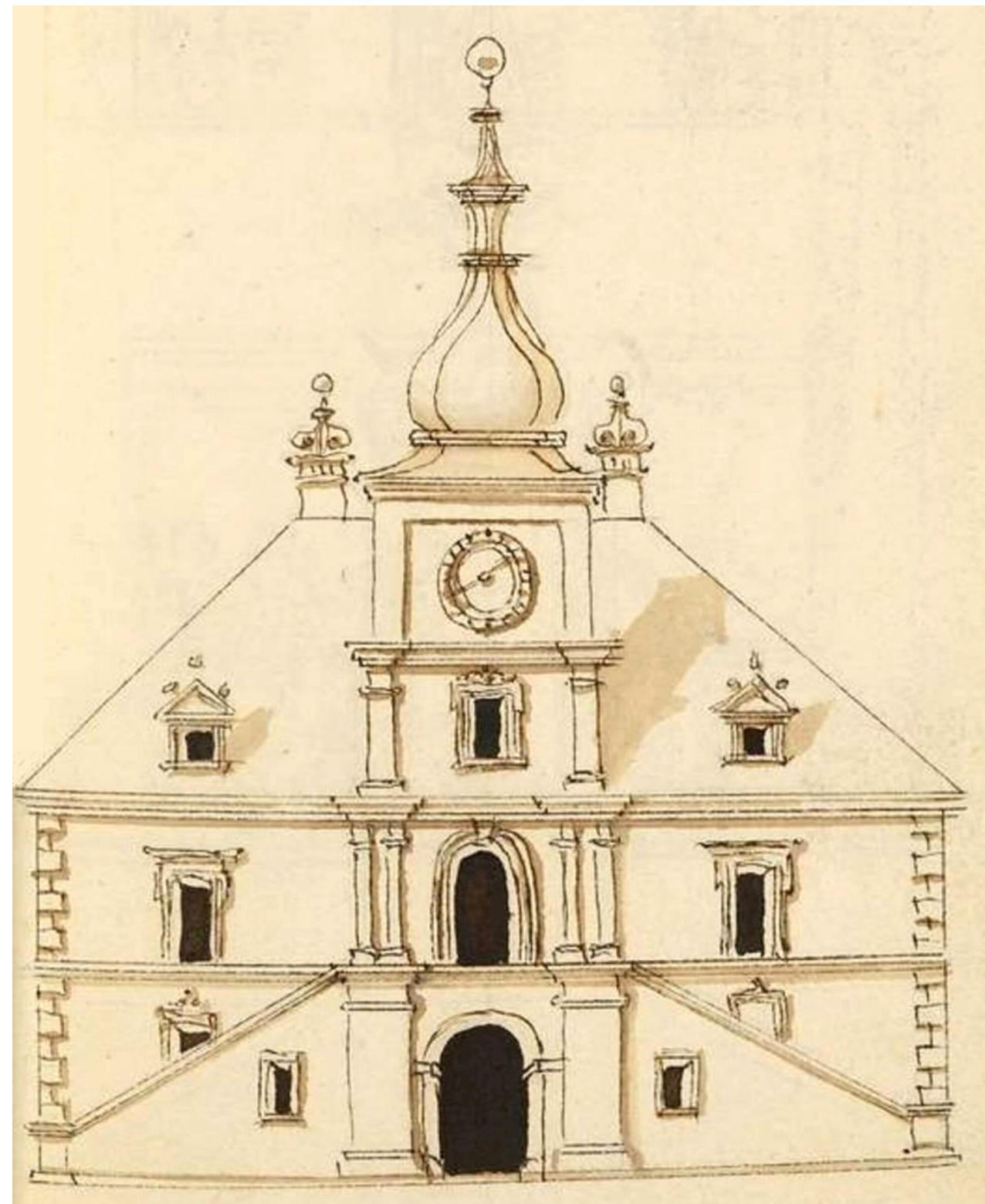

4. G. B. Gisleni, Projekt ratusza na Lesznie - elewacja, ok. 1650, Staatliche Kunstsammlungen Dresden, fot. domena publiczna 


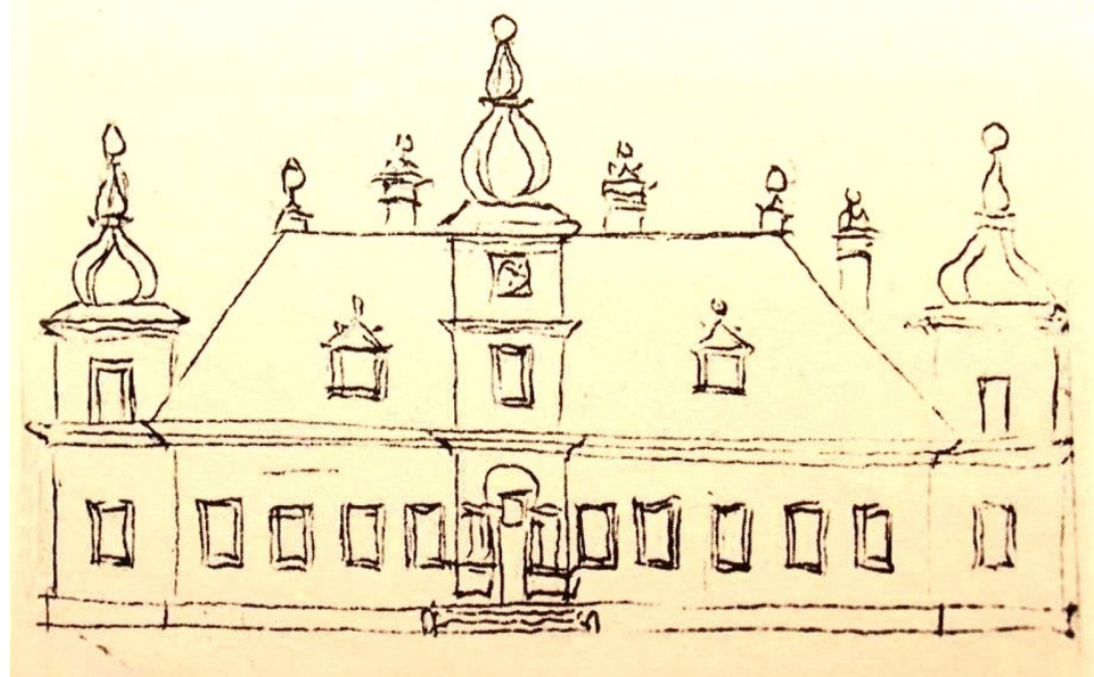

5. G. B. Gisleni, Projekt dworu Opalińskich, ok. 1650, Staatliche Kunstsammlungen Dresden, fot. domena publiczna

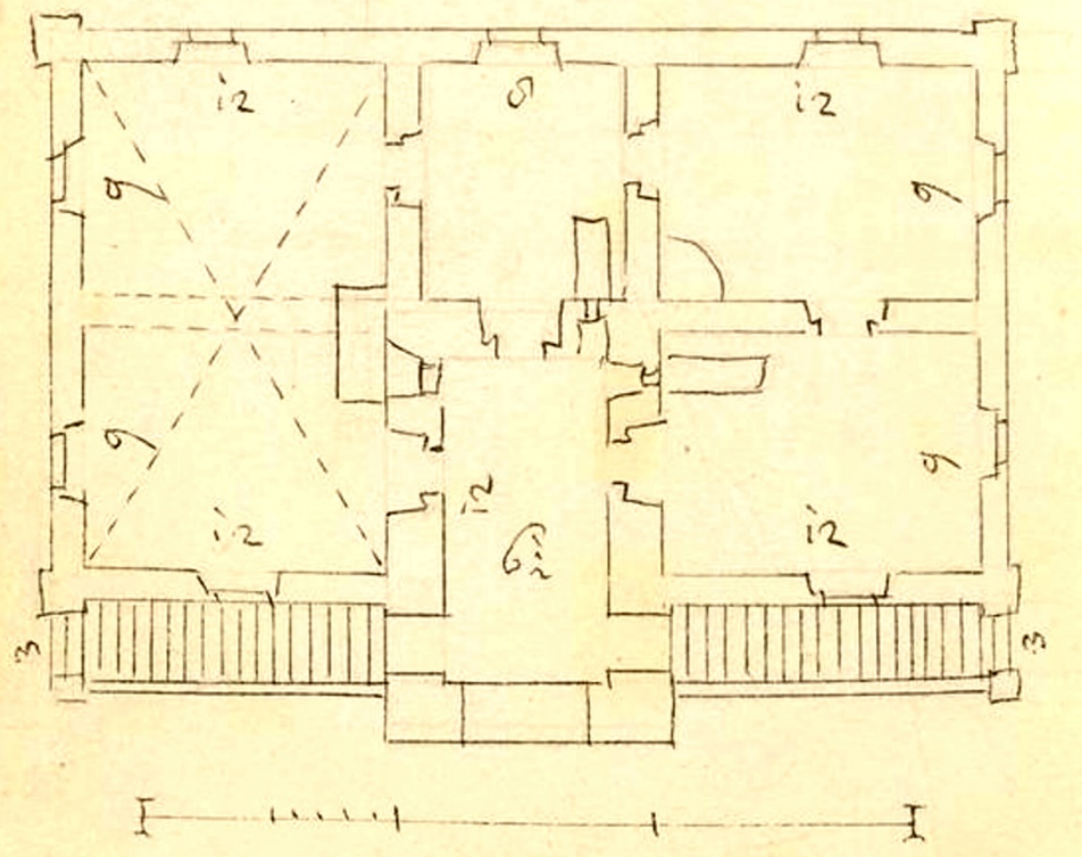

6. G.B. Gisleni, Projekt ratusza na Lesznie - rzut, ok. 1650, Staatliche Kunstsammlungen Dresden, fot. domena publiczna 


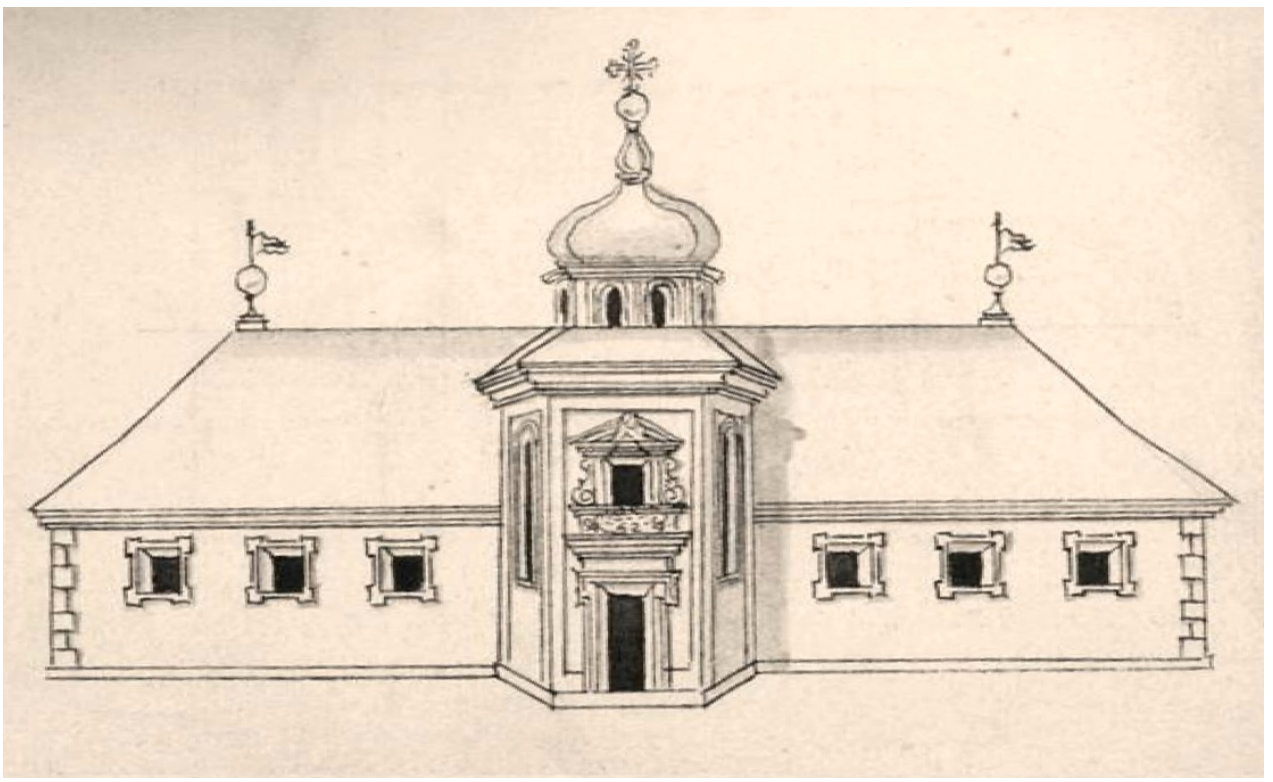

7. G.B. Gisleni, Projekt szpitala na Lesznie - elewacja. Wersja I, ok. 1650, Staatliche Kunstsammlungen Dresden,

fot. domena publiczna

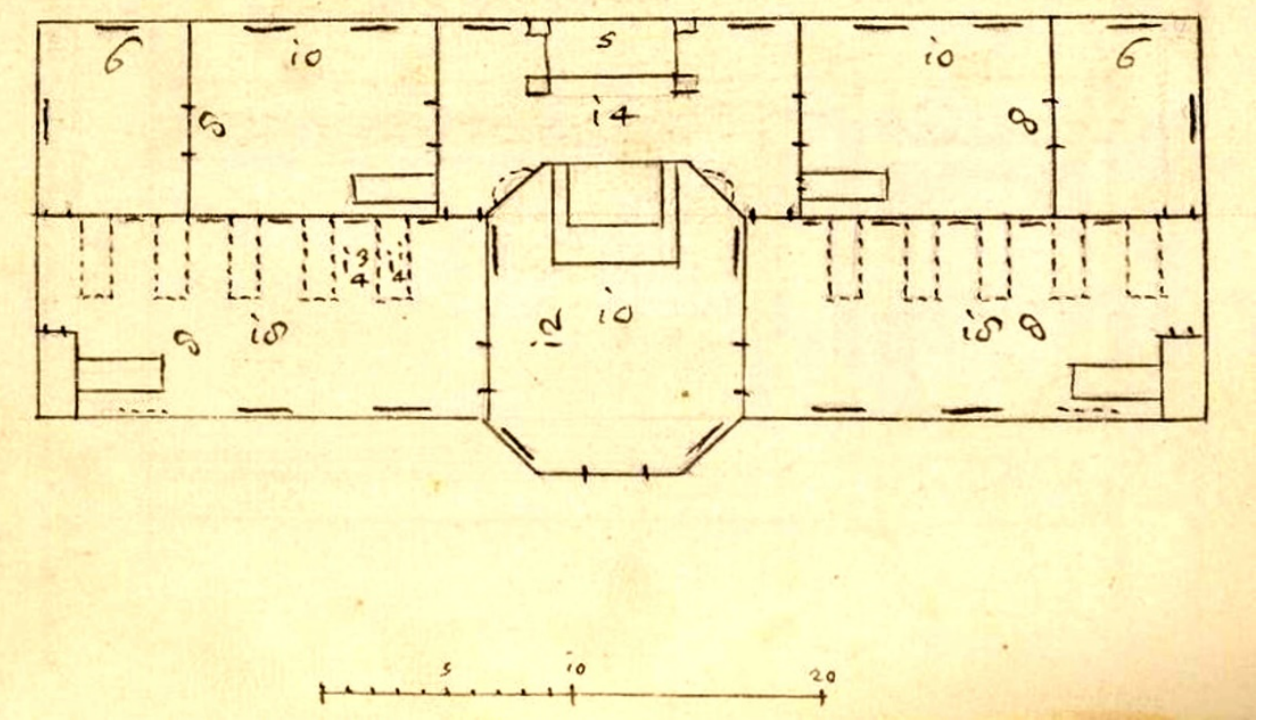

8. G. B. Gisleni, Projekt szpitala na Lesznie - rzut. Wersja I, ok. 1650, Staatliche Kunstsammlungen Dresden,

fot. domena publiczna 


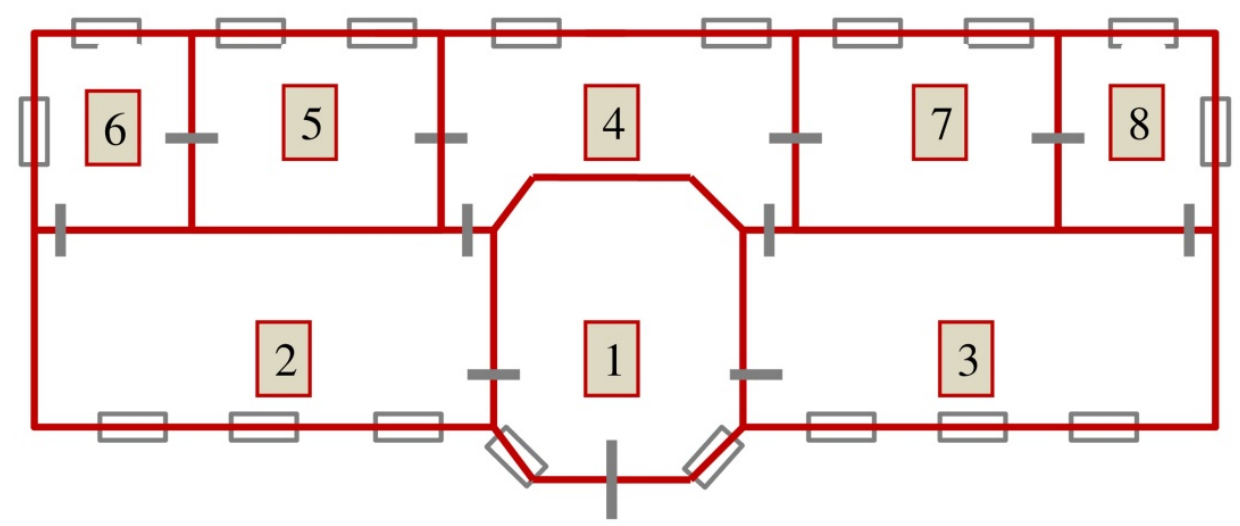

9. Projekt szpitala na warszawskim Lesznie z ok. 1650 r.

Rekonstrukcja układu funkcjonalnego: 1. Kaplica; 2-3. Sale chorych; 4. Kuchnia z refektarzem; 5. Pomieszczenie gospodarcze; 6 . Pokój dla gospodarzy szpitala; 7. Pomieszczenie gospodarcze; 8. Pokój dla gospodarzy szpitala, oprac. Alina Barczyk (na podstawie G.B. Gisleni, Projekt szpitala na Lesznie - rzut. Wersja I, ok. 1650, Staatliche Kunstsammlungen Dresden)

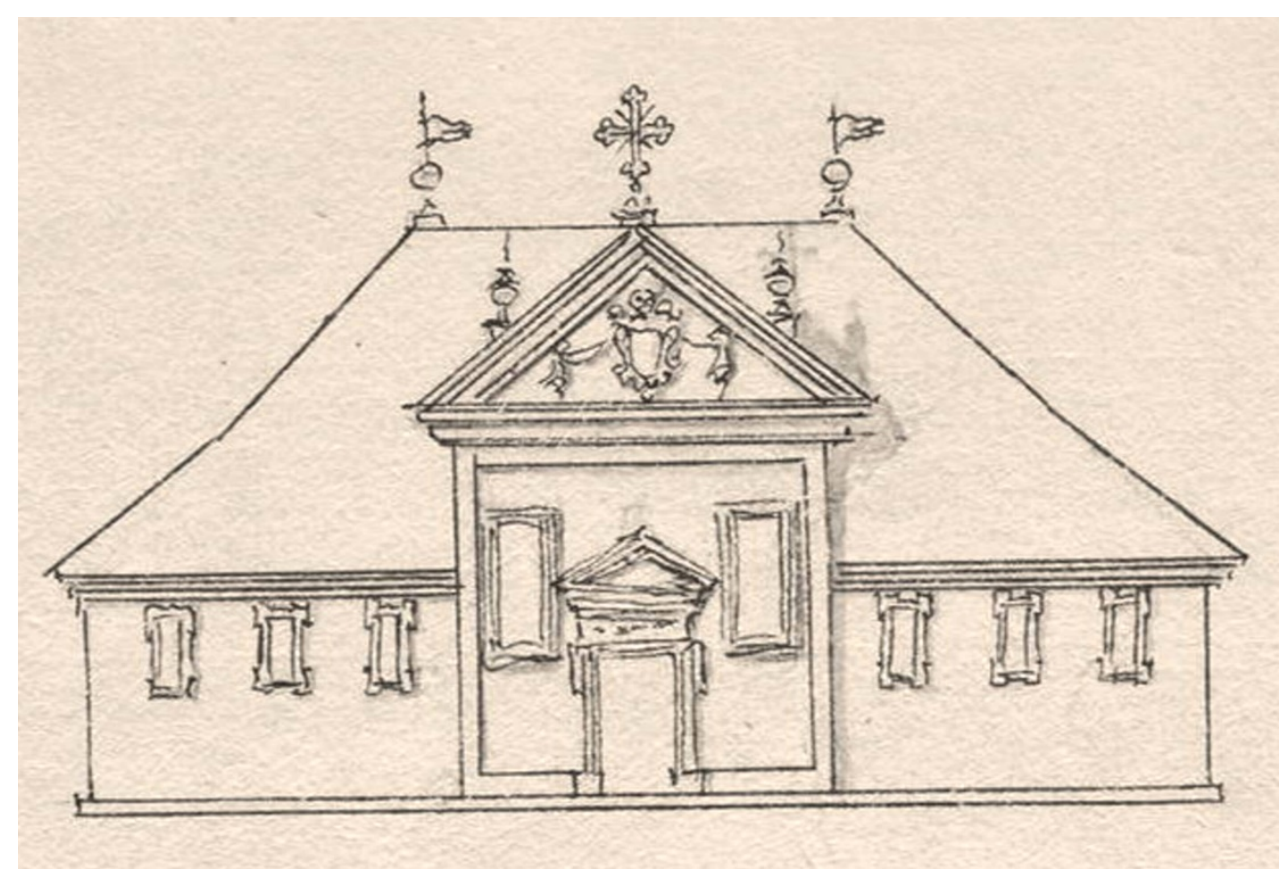

10. G.B. Gisleni, Projekt szpitala na Lesznie - elewacja. Wersja II, ok. 1650, Staatliche Kunstsammlungen Dresden,

fot. domena publiczna 


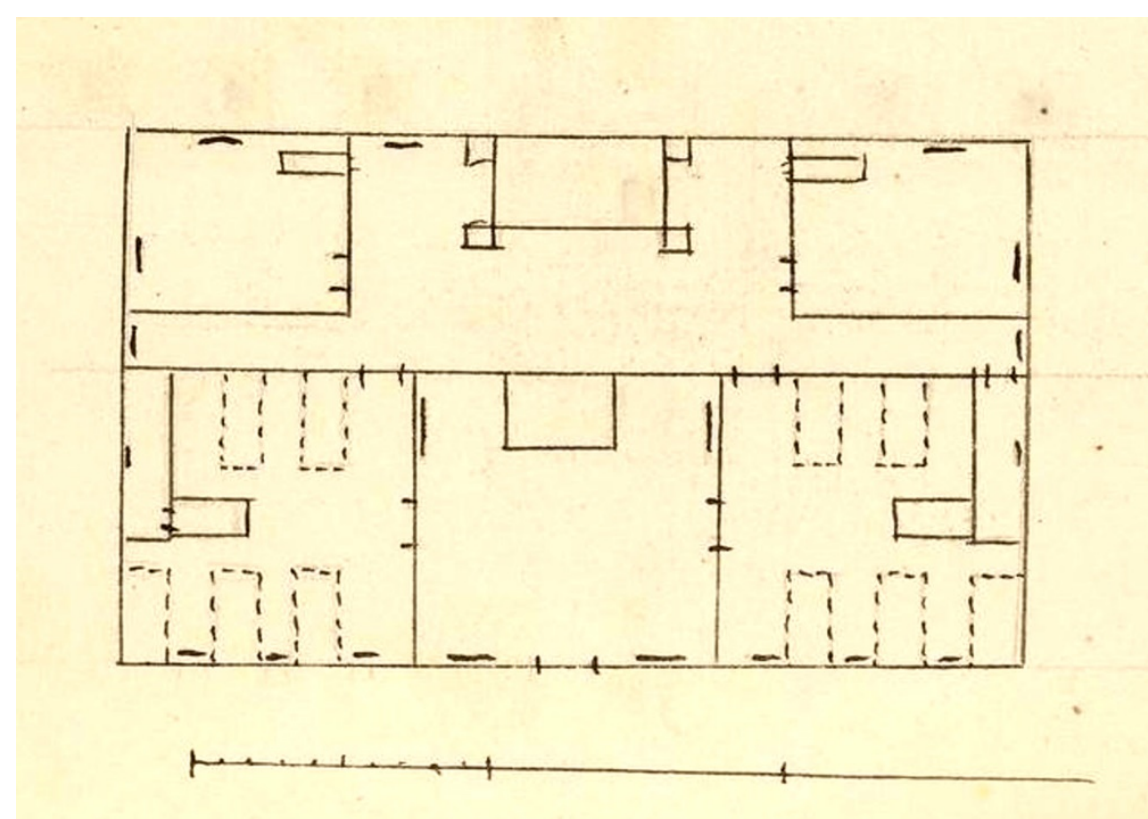

11. G.B. Gisleni, Projekt szpitala na Lesznie - rzut. Wersja II, ok. 1650, Staatliche Kunstsammlungen Dresden, fot. domena publiczna

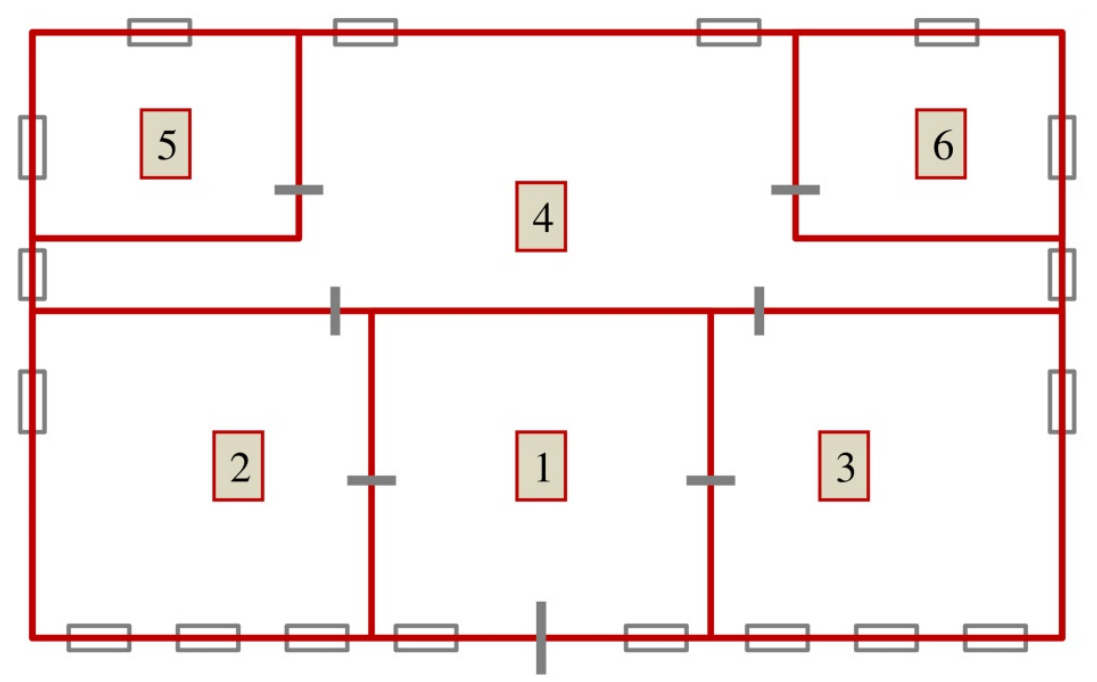

12. Projekt szpitala na warszawskim Lesznie z ok. $1650 \mathrm{r}$.

Rekonstrukcja układu funkcjonalnego: 1. Kaplica; 2-3. Sale chorych; 4. Kuchnia z refektarzem; 5-6. Pomieszczenia gospodarcze/dla gospodarzy szpitala, oprac. Alina Barczyk (na podstawie G.B. Gisleni, Projekt szpitala na Lesznie - rzut. Wersja II, ok. 1650,

Staatliche Kunstsammlungen Dresden) 


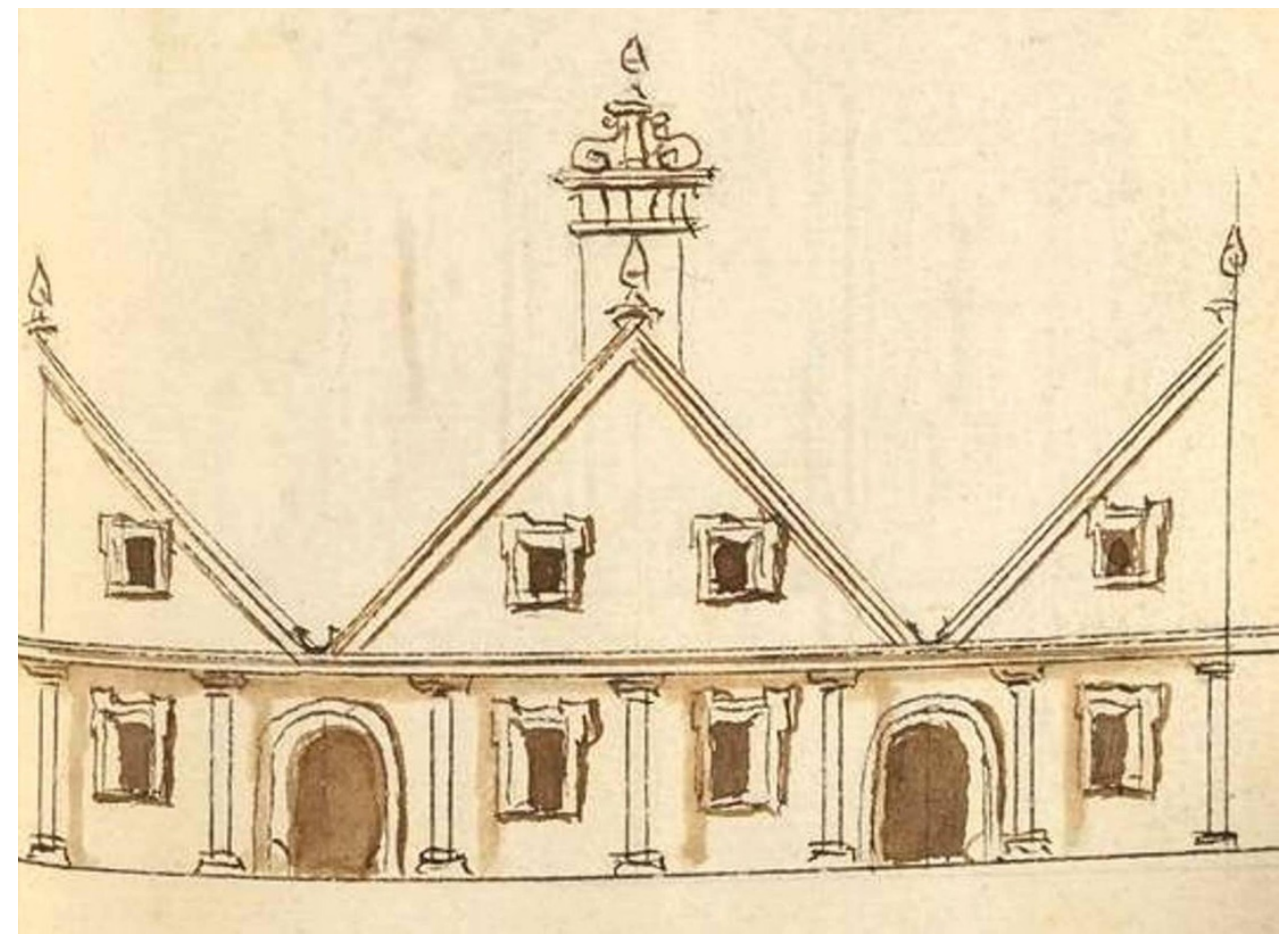

13. G. B. Gisleni, Projekt zabudowy szeregowej na terenie jurydyki Leszno, ok. 1650, Staatliche Kunstsammlungen Dresden,

fot. domena publiczna 